\title{
KONTRIBUSI PENDAPATAN ASLI DAERAH DAN DANA PERIMBANGAN TERHADAP BELANJA MODAL DAN KINERJA KEUANGAN DAERAH PROVINSI BALI
}

\begin{abstract}
Issues that arise in a decentralized government that is when the allocations are not appropriate in capital expenditure as well as the reception is not optimal (PAD, DBH, DAU, and DAK) that impact on the performance of local government. This study aimed to analyze the effect of revenue (PAD) and Fund Balance to the Capital Expenditure and Financial Performance Bali Provincial. The study population was all over the city / regency in Bali. This research technique using census method. The results showed that capital spending is directly positive and significant impact on the financial performance area, equalization funds directly no significant effect on capital expenditure, the balance funds indirectly positive and significant impact on the financial performance areas, PAD direct significant effect on capital spending PAD indirectly no significant negative effect on the financial performance of the region.
\end{abstract}

Keywords: Pad, Balanced Funds, Capital Expenditure, Financial Performance Areas.

\section{PENDAHULUAN}

\section{Latar Belakang}

Kebijakan pengelolaan keuangan daerah tidak terlepas dari kebijakan desentralisasi dan otonomi daerah dengan pembaharuan subjek pengelolaan keuangan daerah yang ada dalam Undang-undang Nomor 32 Tahun 2004 secara ekonomis, efektifitas, dan efisiensi pengelolaan keuangan daerah baik dari sisi pendapatan maupun belanja. Desentralisasi pemerintah daerah kabupaten dan kota menunjukkan kemampuannya dalam pengelolaan terhadap daerahnya masing-masing dalam meningkatkan kinerja mereka. Ini merupakan tantangan bahwa daerah mampu mendesain dan melaksanakan program yang sesuai dengan kondisi lokal yang patut disikapi dengan kepercayaan diri dan tanggung jawab penuh.

Desentralisasi fiscal akan memberikan kewenangan yang lebih besar dalam pengelolaan daerah, sedangkan disisi lain memunculkan persoalan baru. Hal tersebut dikarenakan tingkat kesiapan fiskal daerah yang berbeda-beda (Harianto dan Adi, 2007). Persoalan itu muncul ketika alokasi yang tidak tepat dalam belanja modal serta penerimaan yang belum optimal sumber pendapatan yang diterima pemerintah (PAD, $\mathrm{DBH}, \mathrm{DAU}$, dan DAK), sehingga tentu saja akan memberikan dampak terhadap kinerja pemerintah daerah tersebut. Serta Blazek dan Maceskova (2010) menghasilkan adanya konflik kepentingan di dalam menentukan sasaran hasil kebijakan.

Kinerja keuangan adalah suatu ukuran kinerja yang menggunakan indikator keuangan. Halim (2008) menjelaskan bahwa analisis keuangan adalah usaha mengidentifikasi ciri-ciri keuangan berdasarkan laporan 
keuangan yang tersedia. Dalam organisasi pemerintah untuk mengukur kinerja keuangan ada beberapa ukuran kinerja, yaitu rasio kemandirian keuangan daerah, rasio efektivitas, rasio efisiensi, rasio aktivitas, dan pertumbuhan (Sularso \& Restianto,2011). Juliawati dkk. (2012) mengungkapkan bahwa PAD dan Dana Perimbangan mempunyai pengaruh yang signifikan baik secara simultan maupun secara parsial terhadap kinerja keuangan pemerintah. Nugroho (2012) menemukan pengaruh yang negatif antara belanja modal dengan kinerja keuangan pemerintah secara langsung, tetapi jika ditambahkan PAD sebagai veriabel intervening maka belanja modal dan kinerja keuangan memiliki pengaruh yang positif. Permasalahan muncul ketika adanya kepentingan politik dari lembaga legislatif yang terlibat dalam penyusunan proses anggaran menyebabkan alokasi belanja modal terdistorsi dan sering tidak efektif dalam memecahkan masalah di masyarakat (Keefer dan Khemani, 2003).

Komposisi Belanja Modal yang optimal dalam upaya meningkatkan pelayanan publik dipengaruhi oleh PAD dan DAU (dana alokasi umum) menurut Kurniawati (2010). Ardhani (2011) juga mengungkapkan bahwa variabel yang berkontribusi terhadap besar kecilnya anggaran belanja modal adalah PAD, DAU dan DAK.

\section{Rumusan Masalah}

Dari uraian latar belakang permasalahan di atas, maka yang menjadi pokok permasalahan dalam penelitian ini adalah : bagaimanakah kontribusi PAD terhadap belanja modal Propinsi Bali?, bagaimanakah kontribusi dana perimbangan terhadap belanja modal Propinsi Bali?, bagaimanakah kontribusi belanja modal terhadap kinerja keuangan daerah Propinsi Bali?, bagaimanakah kontribusi PAD terhadap kinerja keuangan daerah Propinsi Bali ?, serta bagaiamanakah kontribusi dana perimbanga terhadap kinerja keuangan daerah Propinsi Bali?

\section{Tujuan Penelitian.}

Berdasarkan rumusan masalah yang diajukan dalam penelitian ini maka tujuan penelitian adalah sebagai berikut; menjelaskan kontribusi PAD terhadap Belanja Modal Provinsi Bali : menjelaskan kontribusi Dana Perimbangan terhadap Belanja Modal Provinsi Bali, menjelaskan kontribusi Belanja Modal terhadap Kinerja Keuangan Daerah Provinsi Bali, menjelaskan kontribusi PAD terhadap Kinerja Keuangan Daerah Provinsi Bali, serta menjelaskan kontribusi Dana Perimbanga terhadap Kinerja Keuangan Daerah Provinsi Bali.

\section{Kegunaan Penelitian}

\section{Manfaat teoritis.}

Penelitian ini diharapkan dapat memberikan sumbangan ilmu pengetahuan, teknologi dan seni khususnya sumbangan bagi akademisi dalam menguji implementasi kebijakan mengenai PAD, dana perimbangan, pengalokasian belanja modal dan peningkatan kinerja keuangan daerah serta bisa menjadi pendukung sekaligus acuan dalam penelitian selanjutnya.

Manfaat praktis 
Sebagai informasi kepada publik dan manajemen Pemerintah Kabupaten dan Kota di Propinsi Bali mengenai Belanja Modal dan Kinerja Keuangan Daerah, sebagai informasi kepada publik dan manajemen Pemerintah mengenai pengaruh belanja modal terhadap pertumbuhan kinerja keuangan daerah, serta sebagai pedoman bagi peneliti lain untuk penelitian selanjutnya tentang kinerja keuangan daerah.

\section{KAJIAN PUSTAKA}

\section{Kinerja Keuangan Pemerintah}

Permendagri No. 13 Tahun 2006 menyebutkan pengertian kinerja sebagai berikut, kinerja adalah keluaran/ hasil dari kegiatan /program yang akan atau telah dicapai sehubungan dengan penggunaan anggaran dengan kuantitas dan kualitas yang terukur. Menurut Halim (2008) analisis kinerja keuangan adalah usaha mengidentifikasi ciri-ciri keuangan berdasarkan laporan keuangan yang tersedia. Dalam organisasi pemerintah untuk mengukur kinerja keuangan ada beberapa ukuran kinerja, yaitu rasio kemandirian, rasio efektifitas, rasio efisiensi, rasio aktivitas, dan rasio pertumbuhan. Pengukuran kinerja keuangan pemerintah daerah dapat diukur dengan menilai efisiensi atas realisasi dari alokasi yang dilakukan pemerintah terhadap suatu anggaran. Indikator kinerja adalah suatu variabel yang digunakan untuk mengekspresikan secara kuantitatif efektivitas dan efisiensi proses atau operasi dengan berpedoman pada target-target dan tujuan organisasi.

\section{Belanja Modal}

Menurut Halim (2008:73), belanja modal merupakan belanja pemerintah daerah yang manfaatnya melebih satu tahun anggaran dan akan menambah aset atau kekayaan daerah dan selanjutnya akan menambah belanja yang bersifat rutin seperti biaya pemeliharaan pada kelompok belanja administrasi umum. Belanja modal digunakan untuk memperoleh aset tetap pemerintah daerah seperti peralatan, infrastruktur, dan harta tetap lainnya. Cara mendapatkan belanja modal dengan membeli melalui proses lelang atau tender Aset tetap yang dimiliki pemerintah daerah sebagai akibat adanya belanja modal merupakan syarat utama dalam memberikan pelayanan publik. pada pasal 53 ayat 4 Permendagri Nomor 59 Tahun 2006 disebutkan bahwa Kepala Daerah menetapkan batas minimal kapitalisasi sebagai dasar pembebanan belanja modal selain memenuhi batas minimal juga pengeluaran anggaran untuk belanja barang tersebut harus memberi manfaat lebih satu periode akuntansi bersifat tidak rutin.

\section{Pendapatan Asli Daerah (PAD).}

Undang-Undang Nomor 17 tahun 2003, pendapatan daerah adalah hak pemerintah daerah yang diakui sebagai penambah nilai kekayaan bersih. (Yuwono, 2005:107) menyatakan bahwa pendapatan daerah adalah semua penerimaan kas yang menjadi hak daerah dan diakui sebagai penambah nilai kekayaan bersih dalam satu tahun anggaran dan tidak perlu dibayar kembali oleh pemerintah. Adapun sumber pendapatan daerah otonom menurut Halim (2004 : 67) adalah: Pendapatan Asli Daerah (PAD), yang terdiri dari: pajak daerah, retribusi daerah, hasil perusahaan dan pengelolaan kekayaan daerah yang dipisahkan, lain-lain Pendapatan 
Asli Daerah yang Sah. Berdasarkan pasal 79 Undang-Undang Nomor 22 Tahun 1999 tentang Pemerintahan Daerah dapat disimpulkan PAD adalah sesuatu yang diperoleh Pemerintah Daerah yang dapat diukur dengan uang karena kewenangan (otoritas) yang diberikan masyarakat dapat berupa hasil pajak daerah dan retribusi daerah, hasil perusahaan milik daerah dan pengelolaan kekayaan daerah serta lain-lain pendapatan daerah yang sah.

\section{Dana Perimbangan.}

Dalam rangka pelaksanaan desentralisasi, kepada daerah diberikan Dana Perimbangan melalui APBN yang bersifat transfer dengan prinsip money follows function.tujuan pemberian Dana Perimbangan tersebut adalah untuk mengurangi kesenjangan fiskal antara pemerintah dengan daerah dan antar daerah, serta meningkatkan kapasitas daerah dalam menggali potensi ekonomi daerah.Dana perimbangan terdiri atas: Dana Bagi Hasil, Dana Alokasi Umum, dan Dana Alokasi Khusus. Pada aspek hubungan pemerintahan pusat dan daerah ini (Elmi, 2002:55) mengungkapkan bahwa dengan adanya kebijakan tersebut diharapkan akan terjadi pembagian keuangan yang adil dan rasional. Artinya bagi daerah-daerah yang memiliki kekayaan sumber daya alam akan memperoleh bagian pendapatan yang jumlahnya lebih besar sedangkan daerahdaerah lainnya akan mengutamakan bagian dari Dana Alokasi Umum (DAU) dan Dana Alokasi Khusus (DAK). Dana Perimbangan adalah dana yang bersumber dari pendapatan APBN yang dialokasikan kepada daerah untuk mendanai kebutuhan daerah dalam rangka pelaksanaan desentralisasi. Dana perimbangan terdiri atas: Dana Bagi Hasil, Dana Alokasi Umum, dan Dana Alokasi Khusus.

\section{Pengaruh PAD terhadap Belanja Modal Kota dan Kabupaten di Propinsi Bali.}

Semua potensi daerah diupayakan dan dikembangkan agar dapat menghasilkan PAD yang dapat membantu untuk menutup belanja daerah. PAD merupakan semua penerimaan daerah yang berasal dari potensi sumber daya yang ada di daerah. Sumber-sumber PAD meliputi hasil pajak daerah, hasil retribusi daerah, hasil perusahaan milik daerah dan hasil pengelolaan kekayaan daerah lainnya yang dipisahkan, lain-lain pendapatan asli daerah yang sah. Pajak dan retribusi daerah mempunyai proporsi terbesar dalam komponen $P A D$, sehingga muncul anggapan bahwa PAD identik dengan pajak dan retribusi daerah. Masih rendahnya kemampuan PAD yang dihasilkan daerah terkait dengan kewajibannya untuk membiayai pengeluaran rutin. Hanya 5 provinsi dan 4 kabupaten dan kota di Indonesia yang memiliki PAD lebih besar daripada kewajiban pembiayaan pengeluaran rutin di tahun 2000. Kurangnya kemampuan daerah dalam memaksimalkan potensi PADnya menjadikan daerah cenderung memiliki ketergantungan pada sumber pendanaan yang lain, yaitu DAU. Beberapa penelitian lain telah dilakukan untuk menguji pengaruh PAD terhadap belanja daerah. Darwanto (2007) menyatakan bahwa Pendapatan Asli Daerah berpengaruh positif dan signifikan terhadap alokasi belanja modal. Darwanto dan Yustikasari (2007) juga menemukan pengaruh yang positif antara PAD dengan belanja modal. 


\section{H1 : PAD berpengaruh positif dan signifikan terhadap belanja modal.}

\section{Pengaruh Dana Perimbangan terhadap Belanja Modal Kota dan Kabupaten di Propinsi Bali.}

Dana perimbangan merupakan dana yang bersumber dari pendapatan APBN yang dialokasikan kepada daerah untuk mendanai kebutuhan daerah dalam rangka pelaksanaan desentralisasi. Dana perimbangan terdiri atas: Dana Bagi Hasil, Dana Alokasi Umum, dan Dana Alokasi Khusus.

Rahardjo (2011) mengatakan bahwa dana bagi hasil berasal dari pajak dan bukan pajak. Sedangkan Prakoso (2004) menyatakan pengurangan jumlah dana bai hasil akan memberikan dampak penurunan terhadap belanja daerah sehingga makan dapat menurunkan belanja modal daerah.

Besarnya nilai DAU dipastikan akan menambah jumlah pendapatan Pemerintah Daerah. Sulistyowati (2011) menemukan pengaruh yang positif antara DAU dan belanja modal.

Sumber pendanaan untuk belanja modal salah satunya berasal dari Dana Alokasi Khusus (DAK). Sulistyowati (2011) menemukan hubungan yang negatif antara DAK terhadap belanja modal.

H2: Dana perimbangan berpengaruh positif dan signifikan terhadap belanja modal.

\section{Pengaruh Belanja Modal terhadap Pertumbuhan Kinerja Keuangan Pemerintah Daerah Kabupaten di Propinsi Bali.}

Pemerintah akan melakukan pembangunan infrastruktur serta sarana dan prasarana yang diperlukan oleh negara, yang tercermin di dalam belanja modal yang dilakukan oleh pemerintah. Belanja modal yang besar merupakan cerminan dari banyaknya infrastruktur dan sarana yang dibangun. Semakin banyak pembangunan yang dilakukan akan meningkatkan pertumbuhan kinerja keuangan daerah, sesuai dengan logika, semakin banyak sumber yang menghasilkan, maka hasilnya pun akan semakin banyak. Hal ini sesuai dengan definisi yang ada sebelumnya, dimana PKKD berarti adalah"peningkatan capaian dari suatu hasil kerja dibidang keuangan daerah yang meliputi anggaran dan realisasi PAD dan Belanja Modal dengan menggunakan indikator keuangan yang ditetapkan melalui suatu kebijakan atau ketentuan perundang-undangan dari satu periode anggaran ke periode anggaran berikutnya".

Nugroho (2012) menemukan bahwa Belanja Modal berpengaruh negatif terhadap kinerja keuangan daerah secara langsung, sedangkan secara tidak langsung melalui PAD, belanja modal berpengaruh positif terhadap pertumbuhan kinerja keuangan daerah. Sedangkan menurut Sularso dan Restianto (2011) menemukan bahwa kinerja keuangan daerah dan belanja modal mempunyai pengaruh yang positif.

\section{H3 : Belanja Modal berpengaruh positif terhadap kinerja keuangan Daerah}

\section{Pengaruh PAD terhadap Pertumbuhan Kinerja Keuangan daerah Kota dan Kabupaten di Propinsi Bali.}

PAD merupakan semua penerimaan daerah yang berasal dari potensi sumber daya yang ada di daerah. Pajak dan retribusi daerah mempunyai proporsi terbesar dalam komponen PAD, sehingga muncul anggapan bahwa PAD identik dengan pajak dan retribusi daerah.. Kurangnya kemampuan daerah dalam memaksimalkan 
potensi PAD-nya menjadikan daerah cenderung memiliki ketergantungan pada sumber pendanaan yang lain, yaitu DAU. Beberapa penelitian lain telah dilakukan untuk menguji pengaruh PAD terhadap pertumbuhan kinerja keuangan daerah. Penelitian Julitawati dkk (2012) menunjukkan adanya pengaruh yang positif antara PAD terhadap pertumbuhan kinerja keuangan daerah. Serta Penelitian Nasution (2010) terhadap kinerja keuangan pemerintah daerah memberikan hasil bahwa secara simultan Pendapatan Asli Daerah (PAD) berpengaruh signifikan terhadap kinerja keuangan pemerintah Kabupaten dan Kota di Propinsi Sumatera Utara.

H4 : PAD berpengaruh positif dan signifikan terhadap Pertumbuhan Kinerja Keuangan daerah.

Pengaruh Dana Perimbangan terhadap Kinerja Keuangan daerah Kota dan Kabupaten di Propinsi Bali.

Dana perimbangan merupakan dana yang bersumber dari pendapatan APBN yang dialokasikan kepada daerah untuk mendanai kebutuhan daerah dalam rangka pelaksanaan desentralisasi. Julitawati (2012) dan Prasasti (2014) menemukan bahwa dana perimbangan mempunyai pengaruh yang negatif terhadap kinerja keuangan daerah.

H5: Dana Perimbangan berpengaruh negatif dan signifikan terhadap Kinerja Keuangan daerah.

\section{METODE PENELITIAN}

\section{Jenis dan Sumber Data}

Jenis data yang digunakan dalam penelitian ini adalah data sekunder. Sumber data dari dokumen laporan realisasi APBD yang diperoleh dari situs Dirjen Perimbangan Keuangan Pemerintah Daerah melalui website www.djpk.depkeu.go.id dan BPS. Dari laporan realisasi APBD tahun 2010-2015 dapat diperoleh data mengenai PAD dan Dana Perimbangan (DBH, DAU, dan DAK), jumlah anggaran Belanja Modal, serta data yang dibutuhkan dalam perhitungan kinerja keuangan daerah.

\section{Variabel Penelitian}

Variabel yang digunakan dalam penelitian ini adalah Pendapatan Asli Daerah, Dana Perimbangan, Belanja Modal, dan Kinerja Keuangan Daerah.

\section{Populasi}

Populasi penelitian ini adalah seluruh pemerintah kota / kabupaten di Propinsi Bali.

Metode Pengumpulan Data

Pengumpulan data penelitian ini dilakukan dengan menggunakan metode dokumentasi.

\section{Teknik Analisis Data}

Teknik analisis yang digunakan dalam penelitian ini meliputi statistik deskriptif, dan statistic inferensial melalui pengujian outer model, pengujian inner model dan uji hipotesis (path coefficients).

\section{HASIL DAN PEMBAHASAN}

Model analisis yang digunakan dalam penelitian ini adalah model persamaan struktural dengan 
pendekatan Partial Least square (PLS). model persamaan struktural penelitian ini seperti terlihat pada Gambar 1 tentang Model Persamaan Struktural Penelitian.

Outer model dengan indicator formatifnya dievaluasi berdasarkan ukuran dan signifikansi dari nilai weightnya. Sebaliknya Model struktural (inner model) dievaluasi dengan melihat R-Square (R2) pada persamaan antar variable laten endogen dengan cara menghitung nilai predictive-relevance (Q2) dan selanjutnya dapat dilihat path pada inner model.

\section{Hasil Model Pengukuran (inner model)}

Evaluasi inner model dapat dilihat dari nilai R-square (R2) pada persamaan antar variable laten endogen dengn cara menghitung nilai predictive-relevance (Q2) dengan rumus : Q2 = 1-(1-R12)(1-R22)...(1-Rp2). Jika Q2 lebih besar dari 0, diinterpretasikan model cukup baik, artinya mampu menjelaskan fenomena variabel Kinerja Keuangan Daerah sebesar nilai Q2 tersebut.

Berdasarkan Nilai R-square (R2) pada Tabel 1 maka dapat dijelaskan bahwa pengaruh variabel PAD, dan dana perimbangan terhadap belanja modal adalah sebesar $46,6 \%$. Hasil ini dapat diinterpretasikan bahwa varibel PAD dan dana perimbangan mampu menjelaskan varians belanja modal sebesar $46,6 \%$ atau belanja modal dipengaruhi oleh PAD dan dana perimbangan sebesar 46,6\%. Nilai R-square sebesar 0,171 juga terdapat pada Kinerja Keuangan Daerah. Nilai ini berarti variabel keuangan daerah mampu dijelaskan oleh variabel PAD, dana perimbangan, dan belanja modal sebesar 17,1\% atau Kinerja keuangan Daerah dipengaruhi oleh PAD, dana perimbangan dan belanja modal sebesar $17,1 \%$.

\section{Pengujian Hipotesis}

Pengujian hipotesis dalam penelitian ini menggunakan model persamaan structural PLS Smart 2.0 M3, dan hasilnya tertera pada Tabel 2 tentang Pengujian Hipotesis.

Berdasarkan Diagram Jalur Hipotesis yang terdapat pada Gambar 2 maka pengaruh antar variabel dapat dijelaskan sebagai berikut :

\section{Pengaruh Pendapatan Asli Daerah (PAD) Terhadap Belanja Modal Di Seluruh Kabupaten/ Kota Provinsi Bali :}

Berdasarkam hasil penelitian, maka PAD secara langsung berpengaruh positif dan signifikan terhadap belanja modal. Hasil penelitian tersebut sejalan dengan penelitian yang dilakukan oleh Darwanto \& Yustikasari (2007), Solikin (207), dan Putro (2011). Pengaruh yang signifikan tersebut tersebut, mengindikasikan bahwa pendapatan asli daerah merupakan sumber pendapatan yang sangat penting bagi pemerintah daerah seluruh kabupaten/kota di Provinsi Bali serta dijadikan acuan dalam penyusunan anggaran belanja modal. Pemerintah daerah di seluruh Kabupaten/Kota di propinsi Bali menjadikan PAD sebagai dasar penyusunan belanja modal.

\section{Pengaruh Dana Perimbangan (DP) Terhadap Belanja Modal Di Seluruh Kabupaten/ Kota Provinsi Bali}

Berdasarkam hasil penelitian, maka dana perimbangan tidak berpengaruh signifikan terhadap belanja modal. Hasil penelitian tersebut sejalan dengan penelitian yang dilakukan oleh Aramana (2011) dan Tuasikal 
(2008). Alokasi belanja modal pemerintah daerah kabupaten/kota tidak tergantung pada besar kecilnya alokasi dana perimbangan atau transfer oleh pemerintah pusat. Ini berarti tingkat kemandirian pemerintah daerah dalam membiayai pembangunan di daerah, terutama untuk belanja modal tidak tergantung pada transfer pemerintah pusat. Bird dan Smart (2002) mengatakan bahwa pola seragam transfer pemerintah pusat secara universal sesuai tapi pengalaman di seluruh dunia membuat jelas bahwa jika layanan harus efisien disediakan, transfer harus dirancang sedemikian rupa sehingga peneriman yang dalam hal ini adalah pemerintah daerah harus memiliki mandat yang jelas, sumber daya yang memadai, fleksibilitas yang cukup untuk membuat keputusan dan bertanggung jawab untuk hasilnya. Hal tersebut membuktikan bahwa alokasi dan penggunaan belanja modal ditentukan oleh kondisi dan pertanggungjawaban dari masing-masing pemerintah daerah terhadap pelayanan masyarakat, bukan berdasarkan dana transfer dari pusat.

\section{Pengaruh Belanja Modal Terhadap Kinerja Keuangan Daerah Seluruh Kabupaten/ Kota Provinsi Bali}

Berdasarkam hasil penelitian, maka belanja modal berpengaruh positif dan signifikan terhadap kinerja keuangan daerah. Hasil penelitian tersebut sejalan dengan penelitian yang dilakukan oleh Sularso dan Restianto (2011). Ketepatan dalam alokasi belanja modal akan dapat menunjukkan kinerja keuangan daerah. Hal ini telah dibuktikan oleh Gomez et al.(2016), dimana untuk mengevaluasi kinerja keuangan dapat diukur dari penyediaan pelayanan bagi masyarakat. Penyediaan layanan ini bisa terwujud jika alokasi belanja modal sudah sesuai dengan kondisi yang diperlukan masyarakat. Masing-masing pemerintah daerah memiliki otorisasi terhadap pelayanan masyarakat yang berbeda-beda. Semakin tinggi otoritas pemerintah daerah terhadap pelayanan masyarakat, maka alokasi belanja modal bagi penyediaan pelayanan akan semakin meningkat sehingga kinerja keuangan pemerintah daerah akan bisa ditingkatkan juga.

\section{Pengaruh Pendapatan Asli Daerah (PAD) Terhadap Kinerja Keuangan Daerah Di Seluruh Kabupaten/ Kota Provinsi Bali}

Berdasarkan hasil penelitian, maka PAD tidak berpengaruh negatif signifikan terhadap kinerja keuangan daerah. Hasil penelitian tersebut sejalan dengan penelitian yang dilakukan oleh Julitawati dkk.(2012), Florida (2006), Wenny (2012). Pendapatan asli daerah tidak memiliki kontribusi dalam pningkatan maupun penurunan kinerja keuangan daerah. Dari hasil penelitian Wenny (2012) menyebutkan bahwa PAD yang merupakan sumber pendapatan daerah tidak seluruhnya dapat mempengaruhi kinerja dikarenakan adanyasumber-sumber yang tidak mempengaruhi kinerja seperti pendapatan restribusi dan pendapatan dari perisahaan daerah. Ini berarti bahwa pemerintah daerah masih menkonsentrasikan pendapatannya dari pajak dan pendapatan lain-lain. Pemerintah daerah masih milhat kinerjanya berdasarkan besar kecilnya pajak yang diperoleh sedangkan sumber pendapatan daerah pemerintah daerah yang masih banyak berpotensi terletak di pendapatan daerah dan pendapatan perusahaan daerah.

Pemerintah daerah Kabupaten/Kota di Propinsi Bali masih tergantung dari penerimaan lain dalam peningkatan kinerja keuangan daerahnya. Dengan kata lain pemerintah daerah belum bisa mengandalakan 
PADnya dalam mengelola daerahnya sendiri, dan masih tergantung dari penerimaan lain, yaitu salah satunya adalah transfer pemerintah pusat yang disebut dengan dana perimbangan.

Dana Perimbangan Terhadap Kinerja Keuangan Daerah Di Seluruh Kabupaten/ Kota Provinsi Bali

Berdasarkam hasil penelitian, maka dana perimbangan berpengaruh positif signifikan terhadap kinerja keuangan daerah. Hasil penelitian tersebut sejalan dengan penelitian yang dilakukan oleh Julitawati dkk., (2012), Florida (2006).

Juliawati dkk.(2012) menyebutkan bahwa transfer dari pemerintah pusat kepada pemeritah daerah dengan tujuan untuk membiayai kelebihan belanja daerah sangat berguna dalam penentuan kinerja keuangan daerah. Ini mengartikan bahwa pemerintah kabupaten/kota di propinsi Bali secara umum masih ketergantungan terhadap transfer pemerintah pusat dalam peningkatan kinerja keuangan. Pemerintah daerah kabupaten/kota di propinsi bali belum bisa mengelola PAD dengan baik sehingga memerlukan transfer pemerintah dalam pembangunan daerahnya. Ini juga sejalan dengan hasil pengujian antara PAD dan Kinerja. Alasan lain pemerintah daerah sangat memerlukan dana perimbangan dalam meningkatkan kinerja keuangan daerah, ditemukan oleh Rodden (2002). Ketergantungan itu dikarenakan adanya kebijakan yang menyulitkan pemerintah daerah dalam mencari sumber pembiayaan terhadap kekurangan belanja daerah. Kebijakan yang rumit dan memojokkan pemerintah daerah, mendorong pemerintah daerah untuk hanya menggunakan dana perimbangan sebagai sumber pendanaan dalam pembiayan belanja karena pemerintah daerah tidak perlu menanggung risiko sebesar pencarian sumber pendanaa lain (pinjaman).

\section{SIMPULAN DAN SARAN}

Dari pokok permasalahan dan hasil pembahasan, maka dapat disimpulkan sebagai berikut : hasil pengujian hipotesis menunjukkan bahwa PAD berpengaruh positif dan siginifikan terhadap belanja modal seluruh kabupaten/kota di Provinsi Bali, Dana Perimbangan tidak berpengaruh positif siginifikan terhadap belanja modal seluruh kabupaten/kota di Provinsi Bali, belanja modal berpengaruh positif dan siginifikan terhadap kinerja keuangan daerah seluruh kabupaten/kota di Provinsi Bali, PAD tidak berpengaruh negatif siginifikan terhadap kinerja keuangan daerah seluruh kabupaten/kota di Provinsi Bali, serta dana perimbangan berpengaruh positif dan siginifikan terhadap kinerja keuangan daerah seluruh kabupaten/kota di Provinsi Bali.

\section{REFERENSI}

Adi, Priyo Hari, dan Harianto. 2007. Hubungan antara Dana Alokasi Umum, Belanja Modal, Pendapatan Asli Daerah dan Pendapatan Per Kapita. Jurnal Kritis: Univeritas Kristen Satya Wacana Salatiga.

Bird R. M. and Smart M. 2002. Intergovernmental Fiscal Transfers: International Lessons for Developing Countries. Elsevier Science Ltd. World Development. Volume 30 Issue 6.

Bisma,I Dewa Gde Bisma dan Santo, Hery, 2010, Evaluasi Kinerja Keuangan Daerah Pemerintah Provinsi Nusa Tenggara Barat Tahun Anggaran 2003 - 2007, GaneÇ Swara. Edisi Khusus Vol. 4 No.3,. 
Blazek J. and Maceskova M.2010. Regional Analysis of Public Capital Expenditure: To Which Regions Is Public Capital Expenditure Channelled - to 'Rich' or to 'Poor' Ones?. 679-696. Journal Regional Studies. Vol 44 Issue 6.

Elmi, B., 2002. Keuangan Pemerintah Daerah Otonom di Indonesia. Jakarta: UI- Press.

Ghozali, Imam. 2011. Aplikasi Analisis Multivariate Dengan Program SPSS. Badan Penerbit Universitas Diponegoro. Semarang.

Gomez J.L.Z, Hernandez A. M. L, and Bastida A. H. 2016. Evaluating financial performance in local government: maximizing the benchmarking value.Sage Journal. International Review of Administrative Sciences. Urban Studies August 1, 2016 53: 2134-2153.

Halim, A., 2008. Analisis Investasi (Belanja Modal) Sektor Publik-Pemerintah Daerah.UPP STIM YKPN. http://www.bppk.depkeu.go.id/index.php/2008050879/jurnalakuntansipemerintah

Jan-Egbert Sturm . 1998. Public Capital Expenditure in OECD Countries. The Causes and Impact of the Decline in Public Capital Spending. 208 pp . ISBN: 978185898827 .Centre of Economic Research, ETH Zürich, Switzerland

Julitawati, Darwanis, dan Jalaluddin. 2012. Pengaruh Pendapatan Asli Daerah (PAD) dan Dana Perimbangan Terhadap Kinerja Keuangan Pemerintah Kabupaten/Kota Di Provinsi Aceh. Jurnal Akuntansi. Volume 1, No. 1, Agustus 2012.Hal 15- 29. Pascasarjana Universitas Syiah Kuala.

Kuncoro,Mudrajat . 2004. Otonomi dan Pembangunan Daerah, Reformasi, Perencanaan, Strategi dan Peluang. Jakarta: Penerbit Airlangga.

Lembaran Negara Republik Indonesia.Peraturan Menteri Dalam Negeri (Permendagri) nomor 13 tahun 2006 tentang Pedoman Pengelolaan Keuangan Daerah.

Mardiasmo. 2002. Otonomi dan Manajemen keuangan daerah. Penerbit Andi: Yogyakarta.

Nurlis. 2016. The Factors Affecting of the Capital Expenditure Allocation Case:The Local Government of Indonesia. Research Journal of Finance and Accounting www.iiste.org ISSN 2222-1697 (Paper) ISSN 2222-2847 (Online) Vol.7, No.1, 2016.

Undang- undang Nomor 17 Tahun 2003 Tentang Keuangan Negara.

Peraturan Pemerintah Republik Indonesia No 58 Tahun 2005 tentang Pengelolaan Keuangan Daerah.

Permendagri No. 13 Tahun 2006 Pasal 36. Tentang Pedoman Pengelolaan Keuangan Daerah.

Prakoso, Kesit Bambang 2004. "Analisa Pengaruh Dana Alokasi Umum (DAU) dan Pendapatan Asli Daerah (PAD)

Terhadap Prediksi Belanja Daerah Studi Empirik Di Wilayah Propinsi Jawa Tengah dan DIY". Jurnal JAAI, Volume 8 Nomor 2, Hal 54-77.

Prakosa, Bambang Kesit. 2011. Analisis Pengaruh DAU dan PAD terhadap Prediksi Belanja Daerah. Jurnal Akuntansi. Universitas Islam Indonesia.

Republik Indonesia.1999. Undang-undang RI No. 22 Tahun 1999 Tentang Perimbangan Keuangan Antara Pemerintah Pusat Dan Daerah.

Republik Indonesia. 2004. Undang-Undang RI No. 33 Tahun 2004 Tentang Perimbangan Keuangan antara 
pemerintah Pusat dengan Pemerintah Daerah

Republik Indonesia.1999. Undang-undang Nomor 25 Tahun 1999 Tentang Perimbangan Keuangan antara Pemerintah Pusat dan Daerah, Jakarta 1999.

Republik Indonesia. 2004. Undang-Undang RI No. 32 Tahun 2004 Tentang Pemerintah Daerah.

Rodden J. 2002. The Dilemma of Fiscal Federalism: Grants and Fiscal Performance around the World. American Journal of Political Science. Vol. 46, No. 3 (Jul., 2002), pp. 670-687

Sekaran, U. 2007. Research Methods for Business (Metodologi Penelitian untuk Bisnis). Penerbit Salemba.

Sidik, M., 2003. Format Hubungan Keuangan Pemerintah Pusat dan Daerah yang Mengacu Pada Pencapaian Tujuan Nasional. Makalah Seminar Nasional, Public Sector Scorecard. Jakarta.

Stepvani Uhise. 2013. Dana Alokasi Umum (Dau) Pengaruhnya Terhadap Pertumbuhan Ekonomi Sulawesi Utara Dengan Belanja Modal Sebagai Variabel Intervening. Jurnal EMBA. Vol.1 No.4 Desember 2013, Hal. 1677-1686.

Sularso, Havid dan Restianto. 2011. Pengaruh Kinerja Keuangan Terhadap alokasi Belanja Modal dan Pertumbuhan Ekonomi Kabupaten/Kota Di Jawa Tengah. Media Riset Akuntansi. Vol 1 no 2 Agustus 2011. Hal 109-123.

Sumarmi, S. 2009. Pengaruh Pendapatan Asli Daerah, Dana Alokasi Umum, Dan Dana Alokasi Khusus Terhadap Alokasi Belanja Modal Daerah Kabupaten/Kota Di Provinsi Di Yogyakarta.diunduh pada tanggal 29 Nopember 2016. http://upy.ac.id/ekonomi/files

Syarifin, Pipin dan Dedah Jubaedah. 2005. Pemerintahan Daerah Di Indonesia. Bandung:CV Pustaka Setia.

Tuasikal, Askam. 2008.Pengaruh DAU, DAK, PAD, Dan PDRB Terhadap Belanja Modal Pemerintah Daerah Kabupaten/Kota Di Indonesia. Jurnal Telaah \& Riset Akuntansi. Vol. 1, No. 2. Juli 2008 Hal.142-155.

Wenny C. D.2012. Analisis Pengaruh Pendapatan Asli Daerah (PAD) Terhadap Kinerja Keuangan Pada Pemerintah Kabupaten dan Kota Di Propinsi Sumatera Selatan. Forum Bisnis Dan Kewirausahaan Jurnal Ilmiah STIE MDP. Vol. 2 No. 1 September 2012.

Wong, J.D. 2004.The Fiscal Impact of Economic Growth and Development on Local Government Capacity. Journal of Public Budgeting. Accounting and Financial Management, Fall, 16.3.

www.djpk.depkeu.go.id

Yustikasari, Yulia, dan Darwanto. 2007. Pengaruh Perumbuhan Ekonomi, Dana Alokasi Umum (DAU) dan Pendapatan Asli Daerah (PAD) terhadap Pengalokasian Anggaran Belanja Modal. Jurnal Kritis. Univeritas Gadjah Mada Yogyakarta.

Yuwono, S. dkk., 2005. Penganggaran Sektor Publik. Surabaya: Bayumedia Publishing. 


\section{LAMPIRAN}

\section{Gambar 1}

Model Persamaan Struktural Penelitian

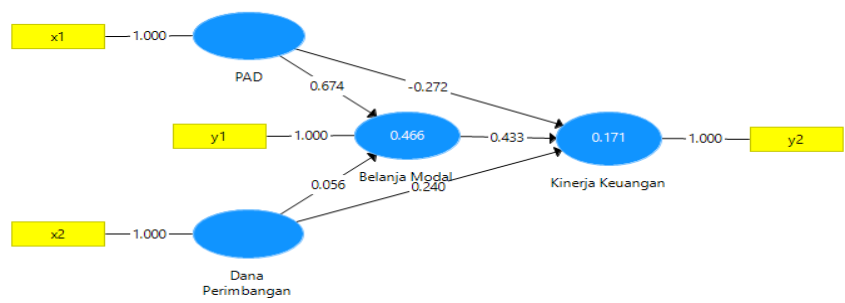

Sumber : Hasil eksekusi PLS (output PLS)

Gambar 2

Diagram Jalur Uji Hipotesis

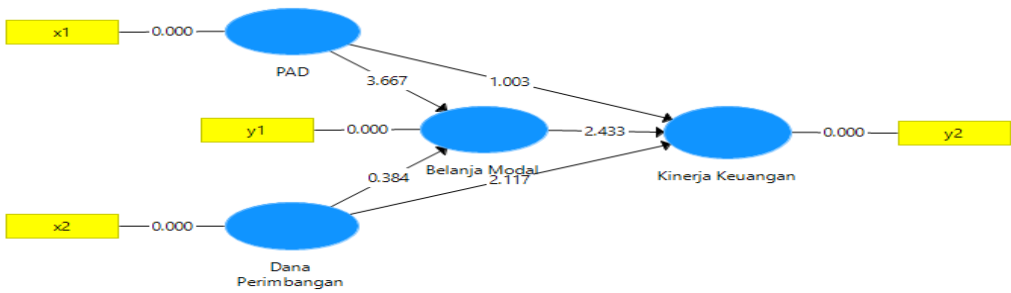

Tabel 1

Nilai R-square (R2) Variabel Laten Endogen

\begin{tabular}{lc}
\hline \multicolumn{1}{c}{ Variabel Laten } & R2 \\
\hline PAD & \\
\hline DP & \\
\hline Belanja Modal & 0,466 \\
\hline Kinerja Keuangan Daerah & 0.171 \\
\hline
\end{tabular}

Tabel 2

Hasil Pengujian Hipotesis

\begin{tabular}{lrrr}
\hline \multicolumn{1}{c}{ Hipotesis } & Original Sample & \multicolumn{1}{c}{ T-Statistics } & \multicolumn{1}{c}{ P Value } \\
\hline BM à KKD & 0,433 & 2,433 & 0,015 \\
\hline DP à BM & 0,056 & 0,384 & 0,701 \\
\hline DPà KKD & 0,240 & 2,117 & 0,035 \\
\hline PAD à BM & 0,674 & 3,667 & 0,000 \\
\hline PAD à KKD & $-0,272$ & 1,003 & 0,316 \\
\hline
\end{tabular}

Jurnal Akuntansi Indonesia 